\title{
HDAC4 Gene
}

National Cancer Institute

\section{Source}

National Cancer Institute. HDAC4 Gene. NCI Thesaurus. Code C26498.

This gene is involved in chromatin remodeling, repression of gene expression and myoblast differentiation. 